Article

\title{
Reduction of Nitrogen Fertilizer Requirements and Nitrous Oxide Emissions Using Legume Cover Crops in a No-Tillage Sorghum Production System
}

\author{
G. Y. Mahama ${ }^{1,2}$, P. V. V. Prasad ${ }^{1, * \mathbb{C}}$, K. L. Roozeboom ${ }^{1}{ }^{\mathbb{D}}$, J. B. Nippert ${ }^{3}$ and C. W. Rice $^{1} \mathbb{D}$ \\ 1 Department of Agronomy, 2004 Throckmorton Plant Science Center, Kansas State University, Manhattan, \\ KS 66506, USA; yakubu.mg@gmail.com (G.Y.M.); kraig@ksu.edu (K.L.R.); cwrice@ksu.edu (C.W.R.) \\ 2 Council for Scientific and Industrial Research-Savanna Agricultural Research Institute, \\ P.O. Box $494 \mathrm{Wa}$, Ghana \\ 3 Division of Biology, 116 Ackert Hall, Kansas State University, Manhattan, KS 66506, USA; nippert@ksu.edu \\ * Correspondence: vara@ksu.edu; Tel.: +1-(785)-532-3746
}

Received: 28 April 2020; Accepted: 25 May 2020; Published: 28 May 2020

check for updates

\begin{abstract}
Nitrous oxide $\left(\mathrm{N}_{2} \mathrm{O}\right)$ emission from denitrification in agricultural soils often increases with nitrogen $(\mathrm{N})$ fertilizer and soil nitrate $\left(\mathrm{NO}_{3}{ }^{-}\right)$concentrations. Our hypothesis is that legume cover crops can improve efficiency of $\mathrm{N}$ fertilizer and can decrease $\mathrm{N}_{2} \mathrm{O}$ emissions compared to non-cover crop systems. The objectives of this study were to (a) evaluate the performance of summer leguminous cover crops in terms of $\mathrm{N}$ uptake and carbon (C) accumulation following winter wheat and (b) to quantify the effects of summer leguminous cover crops and $\mathrm{N}$ fertilizer rates on $\mathrm{N}_{2} \mathrm{O}$ emissions and grain yield of the subsequent grain sorghum crop. Field experiments were conducted in the context of a wheat-sorghum rotation for two seasons in Kansas. Treatments consisted of double-cropped leguminous cover crops following winter wheat harvest with no fertilizer applied to the following grain sorghum or no cover crop after wheat harvest and $\mathrm{N}$ fertilizer rates applied to the grain sorghum. The cover crops were cowpea (Vigna unguiculata L. Walp.), pigeon pea (Cajanus cajan L. Millsp.), and sunn hemp (Crotalaria juncea L.). The three $\mathrm{N}$ treatments (were 0,90 , and $180 \mathrm{~kg} \cdot \mathrm{N} \cdot \mathrm{ha}{ }^{-1}$ ). Fallow systems with 90 and $180 \mathrm{~kg} \cdot \mathrm{N} \cdot \mathrm{ha}^{-1}$ produced significantly greater $\mathrm{N}_{2} \mathrm{O}$ emissions compared with cropping systems that received no $\mathrm{N}$ fertilizer. Emissions of $\mathrm{N}_{2} \mathrm{O}$ were similar for various cover crops and fallow systems with $0 \mathrm{~kg} \cdot \mathrm{N} \cdot \mathrm{ha}^{-1}$. Among cover crops, pigeon pea and cowpea had greater $\mathrm{C}$ accumulation and $\mathrm{N}$ uptake than sunn hemp. Grain yield of sorghum following different cover crops was similar and significantly higher than fallow systems with $0 \mathrm{~kg} \cdot \mathrm{N} \cdot \mathrm{ha}^{-1}$. Although fallow systems with 90 and $180 \mathrm{~kg} \cdot \mathrm{N} \cdot \mathrm{ha}^{-1}$ produced maximum sorghum grain yields, $\mathrm{N}_{2} \mathrm{O}$ emissions per unit of grain yield decreased as the amount of $\mathrm{N}$ fertilizer was reduced. We conclude that including leguminous cover crops can decrease $\mathrm{N}$ fertilizer requirements for a subsequent sorghum crop, potentially reducing $\mathrm{N}_{2} \mathrm{O}$ emissions per unit grain yield and providing options for adaptation to and mitigation of climate change.
\end{abstract}

Keywords: crop rotation; cover crops; greenhouse gas emissions; legumes; nitrogen management; nitrous oxide; cropping system; sorghum

\section{Introduction}

One of the challenges for agriculture is to minimize nitrogen $(\mathrm{N})$ losses to the environment while maintaining adequate $\mathrm{N}$ supply for high cash crop yields [1]. These losses are primarily the result of timing asynchrony of the supply or availability of nitrogen and crop demand along with environmental factors. Of particular environmental concern are emissions of nitrous oxide $\left(\mathrm{N}_{2} \mathrm{O}\right)$, a greenhouse gas (GHG) from agricultural soils that contributes to global warming and ozone destruction. Although 
emissions of $\mathrm{N}_{2} \mathrm{O}$ are smaller in magnitude than those of other GHGs such as carbon dioxide, they are a major contributor (about 15\%) to global warming [2] because the global warming potential of $\mathrm{N}_{2} \mathrm{O}$ is about 298 times greater than that of $\mathrm{CO}_{2}$ [3]. In addition, $\mathrm{N}_{2} \mathrm{O}$ destroys the stratospheric ozone, which is a major concern [4].

Agricultural soils are known to be the largest anthropogenic source of $\mathrm{N}_{2} \mathrm{O}$ [5]. Decreasing $\mathrm{N}_{2} \mathrm{O}$ emissions from field-crop soils is necessary from not only an environmental quality perspective, but also an agro-economic perspective, because it decreases the efficacy of expensive applied $\mathrm{N}$ fertilizers. The challenge for field-crop producers is that underuse of $\mathrm{N}$ fertilizer can result in lower crop yields, but overuse results in excess soil inorganic $\mathrm{N}$, which may be lost as $\mathrm{N}_{2} \mathrm{O}$ and/or leach as nitrate $\left(\mathrm{NO}_{3}{ }^{-}\right)$into surface and groundwater resources. Over-applying fertilizer $\mathrm{N}$ simultaneously pollutes the environment and wastes an expensive crop nutrient. Maintaining the right amount of $\mathrm{N}$ in the root zone throughout the growing season is extremely difficult, but important [6]. Therefore, developing crop and soil management practices for efficient use of $\mathrm{N}$ and to minimize $\mathrm{N}_{2} \mathrm{O}$ emissions is important. Use of summer legume cover crops in the farming systems is one such management practice to improve soil health, reduce environmental pollution, and improve crop yields [7].

Leguminous cover crops have the capacity to fix atmospheric $\mathrm{N}$ through biologic nitrogen fixation (BNF), thus decreasing fertilizer $\mathrm{N}$ demand in the following cereal and oil seed crops, because soil mineral $\mathrm{N}$ availability is greater in the year following legumes [8]. In addition, use of leguminous cover crops can decrease disease and weed pressure, particularly in cereal based cropping systems [9]. The benefits of legume cover crops or grain crops in rotation with cereal crops is largely attributable to improved N supply, improvement in soil physical and chemical properties such as bulk density, water-holding capacity, and improved cation exchange capacity because of soil organic matter increase over time [10].

The effects of cover crops on $\mathrm{N}_{2} \mathrm{O}$ emissions are mixed [11]. Short-term peaks in $\mathrm{N}_{2} \mathrm{O}$ emissions often were observed after crop residues are returned to the soil [12]. The magnitude of the emissions depends on environmental conditions, such as temperature and rainfall, and the quantity of plant residue added to the soil. The influence of summer leguminous cover crops in rotation systems with cereals or fallow on $\mathrm{N}_{2} \mathrm{O}$ emissions during the cropping season is not understood. Research conducted by Garcia-Ruiz and Baggs (2007) [13] reported $\mathrm{N}_{2} \mathrm{O}$ emissions up to three times greater in a soil with a legume residue input than in a non-amended soil, but the magnitude of response to legume residue addition depends on environmental and soil conditions [14].

Cover crop adoption is increasing substantially throughout the US [15,16], especially in the Midwest and in the mid-Atlantic states [17], including Maryland, Pennsylvania and Virginia. These states also have a high concentration of animal husbandry; thus, it may be possible to couple excess manure from animal production with cover crop selection to improve $\mathrm{N}$ management and reduce nitrous oxides emissions. Therefore, understanding $\mathrm{N}_{2} \mathrm{O}$ emissions from leguminous cover crops and $\mathrm{N}$ fertilizers and/or amendments in cropping systems is particularly important. This is because cover crops are increasingly promoted as components of GHG mitigation strategies [18] and integrated soil management strategies, especially in Sub-Saharan Africa. Synthetic fertilizer N use in Africa is lower when expressed on an area basis than on any other continent, and inadequate availability of synthetic $\mathrm{N}$ often limits the production of agricultural crops. For this reason, alternative sources of nutrients such as leguminous cover crops to improve crop production and the same time reducing $\mathrm{N}_{2} \mathrm{O}$ emission are critical for mitigating the negative impact of $\mathrm{N}_{2} \mathrm{O}$ to the atmosphere.

Our hypothesis is that legume cover crops can improve efficiency of $\mathrm{N}$ fertilizer and can decrease $\mathrm{N}_{2} \mathrm{O}$ emissions compared to non-cover crop systems. The objectives of this study were (a) to evaluate the performance of leguminous summer cover crops for $\mathrm{N}$ uptake and carbon (C) accumulation following winter wheat, and (b) to quantify the effects of leguminous summer cover crops and $\mathrm{N}$ fertilizer on $\mathrm{N}_{2} \mathrm{O}$ emissions and grain yield of the subsequent grain sorghum (Sorghum bicolor $\mathrm{L}$. Moench) crop. 


\section{Materials and Methods}

\subsection{Study Site and Experimental Design}

On-station trials were carried out during the cropping seasons of 2012/2013 and 2013/2014. The study site was at the Kansas State University (KSU) Department of Agronomy research facility located at the Agronomy North Farm (39 $11^{\prime} 30^{\prime \prime}$ N, 96 $35^{\prime} 30^{\prime \prime}$ W, $308 \mathrm{~m}$ above sea level) on well-drained Kennebec silt loam (fine-silty, mixed, superactive, mesic Cumulic Hapludolls).

Treatments in this cropping system included no-tillage double-cropped leguminous cover crops following winter wheat variety, cv. Everest rotated with grain sorghum hybrid DKS54-00 and N fertilizer rates applied to the grain sorghum. The experimental design was a randomized complete block design with four replications. The plot size was $4.5 \mathrm{~m} \times 9.0 \mathrm{~m}$.

Each block included a randomized arrangement of six treatments assigned to the six experimental units in each block. Three treatments included no cover crops after wheat, but with three $\mathrm{N}$ rates $(0,90$, and $\left.180 \mathrm{~kg} \cdot \mathrm{N} \cdot \mathrm{ha}^{-1}\right)$ applied as dry urea $(46 \% \mathrm{~N}$ by weight) at time of grain sorghum planting. The other three treatments included cover crops (CC); cowpea, Vigna unguiculata L. Walp., California black eye variety; pigeon pea, Cajanus cajan L. Millsp., White Bold variety; and sunn hemp, Crotalaria juncea L., but with no $\mathrm{N}$ fertilizer applied at the time of grain sorghum planting as presented in Table 1 and field layout as shown in Table 2.

Table 1. Treatment description of the experiment during the growing seasons.

\begin{tabular}{ccc}
\hline Treatment Code & $\begin{array}{c}\text { Cover Crop Planted after Winter Wheat } \\
\text { Harvest (CC) }\end{array}$ & $\begin{array}{c}\text { Nitrogen Fertilizer Applied to Sorghum } \\
\text { at Planting (kg.ha } \mathbf{~} \mathbf{~} \text { ) }\end{array}$ \\
\hline $0 \mathrm{~N}$ & None & 0 \\
$90 \mathrm{~N}$ & None & 90 \\
$180 \mathrm{~N}$ & None & 180 \\
$\mathrm{CP}$ & Cowpea & 0 \\
$\mathrm{PG}$ & Vigna unguiculata L. Walp. \\
Pigeon pea & 0 \\
$\mathrm{SU}$ & Cajanus cajan L. Millsp. \\
Sunn hemp & 0 \\
\hline
\end{tabular}

Table 2. Field plan showing plots/treatments in the experiment during the growing seasons. For details of the treatments, see Table 1.

\begin{tabular}{cccc}
\hline $101,180 \mathrm{~N}$ & $106, \mathrm{NN}$ & $201, \mathrm{CP}$ & $206,0 \mathrm{~N}$ \\
$102, \mathrm{SU}$ & $105, \mathrm{CP}$ & $202,180 \mathrm{~N}$ & $205,90 \mathrm{~N}$ \\
$103,90 \mathrm{~N}$ & $104, \mathrm{PG}$ & $203, \mathrm{SU}$ & $204, \mathrm{PG}$ \\
$301,0 \mathrm{~N}$ & $306, \mathrm{CP}$ & $401, \mathrm{PG}$ & $406, \mathrm{SU}$ \\
$302,90 \mathrm{~N}$ & $305, \mathrm{PG}$ & $402, \mathrm{CP}$ & $405,180 \mathrm{~N}$ \\
$303,180 \mathrm{~N}$ & $304, \mathrm{SU}$ & $403, \mathrm{~N}$ & $404,90 \mathrm{~N}$ \\
\hline
\end{tabular}

Treatments without cover crops but with the three $\mathrm{N}$ fertilizer rates established $\mathrm{N}_{2} \mathrm{O}$ emission and sorghum responses to $\mathrm{N}$ fertilizer that were used to contextualize responses to legume cover crops as well as to estimate equivalent $\mathrm{N}$ contributions from legume cover crops to the subsequent sorghum crop [19].

\subsection{Management of Winter Wheat, Cover Crops, and Grain Sorghum}

Winter wheat was drilled in October 2011 and 2012. Before seeding the wheat, glyphosate-4 plus herbicide [N-(phosphonomethyl) glycine] at a rate of 1.67 a.i. $\mathrm{kg} \cdot \mathrm{L}^{-1}$ was applied with a backpack knapsack sprayer to kill all weeds in the field. Seeding was performed with a John Deere 1590 (Deere \& Co., Moline, IL, USA) with a target seeding rate of $115 \mathrm{~kg} \cdot \mathrm{L}^{-1}$ with inter row spacing of 
$19 \mathrm{~cm}$. Nitrogen fertilizer in the form of liquid urea ammonium nitrate solution $(28 \% \mathrm{~N})$ was applied at the rate of $68 \mathrm{~kg} \cdot \mathrm{N} \cdot \mathrm{ha}^{-1}$ with $20 \mathrm{~kg} \cdot \mathrm{N} \cdot \mathrm{ha}^{-1}$ applied at wheat planting and $48 \mathrm{~kg} \mathrm{~N} \mathrm{ha}{ }^{-1}$ applied at spring green up in both years. After wheat harvest in June (2012) and July (2013), the stubble was sprayed with $3.5 \mathrm{~L} \cdot h \mathrm{a}^{-1}$ glyphosate 4 plus herbicide ( $N$-(phosphonomethyl) glycine) to control weeds. After harvesting the wheat, three leguminous CC (cowpea, pigeon pea, and sunn hemp) were planted into the wheat stubble without tillage. Before planting the cover crops, seeds were treated with a commercial Rhizobium inoculant at rate of $1 \mathrm{~kg}$ of seed to $5 \mathrm{~g}$ of inoculants. The seeding rate used for cowpea, pigeon pea, and sunn hemp was 56,28 , and $12.5 \mathrm{~kg} \cdot \mathrm{ha}^{-1}$, respectively. Planting was carried out on 17 June 2012 and 8 July 2013.

Cowpea, pigeon pea, and sunn hemp were terminated 69, 86, and 87 days after planting, respectively, in 2012. Corresponding values in 2013 were 72, 88, and 89 days after planting. Cover crop aboveground biomass production was estimated by harvesting an area of $4.5 \mathrm{~m}^{2}$ at two spots from all CC plots by hand in 2012 and 2013. After weighing, fresh CC aboveground biomass sub-samples of roughly $1000 \mathrm{~g}$ of the CC were obtained. The remaining CC aboveground biomass was distributed uniformly on the harvested plots to decompose and act as dead mulch for the subsequent grain sorghum crop. The two subsamples of aboveground biomass from each CC plots were dried in a forced-air dryer at $65{ }^{\circ} \mathrm{C}$ until they reached constant weight. The dried CC aboveground biomass (leaves and stems) of the sub-samples were used to calculate dry matter content of harvested material, which was used to adjust plot fresh weights for estimates of total dry CC aboveground biomass production. The dried CC aboveground biomass samples (leaves and stems) were ground in a Thomas Wiley laboratory mill (Model 4, Arthur H. Thomas Company, Philadelphia, PA, USA) and passed through a 2.0-mm screen. The dried CC aboveground biomass samples were analyzed for $\mathrm{N}$ and C by dry combustion (modified Dumas method) using a LECO CHN-2000 elemental analyzer (LECO Corp., St. Joseph, MI, USA) by the Kansas State University Soil Testing Laboratory. Nitrogen and $\mathrm{C}$ accumulation in the aboveground biomass of the $\mathrm{CC}$ were determined by multiplying mass of aboveground dry matter by percentage $\mathrm{N}$ concentration or percentage $\mathrm{C}$ concentration. The succeeding grain sorghum (DKS54-00) crop was planted in May (2013) and June (2014) with a two-row planter (John Deere 1590, Deere \& Co.) without tillage. Weeds on the experimental field were sprayed with 3.5 L ha ${ }^{-1}$ glyphosate 4 plus herbicide [N-(phosphonomethyl) glycine] before planting. Standard spacing for sorghum (75 cm between rows) was used during planting in both years with a target plant population of 125,000 plants ha $^{-1}$. Weeds were controlled with pre-emergence herbicide, atrazine (1-chloro-3-ethylamino-5-isopropylamino-2,4,6-triazine) and 2,4-dichlorophenoxyacetic acid (2,4-D) sprayed at the rate of $1.1 \mathrm{~L} \cdot \mathrm{ha}^{-1}$, with a tractor-mounted boom sprayer. Hand-weeding was also done when necessary throughout the growing season to keep fields weed-free.

Each sorghum plot was sampled at physiological maturity and separated into leaf, stem, and panicle components from ten randomly selected plants in the two inner rows. The samples were dried for $72 \mathrm{~h}$ at $60^{\circ} \mathrm{C}$ in a forced-air oven. Total aboveground biomass was calculated and expressed in $\mathrm{kg} \cdot \mathrm{ha}^{-1}$ based on plant population in each plot. Grain sorghum panicles were hand threshed, and the grains ground with the aid of a Cyclone sample mill (Model 3010-030, Udy Corporation, Fort Collins, CO, USA). A Thomas Wiley laboratory mill was used to grind the leaves and stems. Leaf, stem, and grain $\mathrm{N}$ were analyzed by the Kansas State University Soil Testing Laboratory. Aboveground N uptake and grain $\mathrm{N}$ uptake of grain sorghum were determined by multiplying dry matter mass by percentage $\mathrm{N}$ concentration of each component. At physiological maturity, plots were harvested using a 2-row Gleaner (modified EIII, AGCO Corporation, Duluth, GA, USA). Grain yields in both years were corrected to $135 \mathrm{~g} \cdot \mathrm{kg}^{-1}$ moisture content.

\subsection{Soil Gas Sampling and Analyses}

Soil gas samples were collected using custom-built static polyvinyl chloride (PVC) chambers designed in accordance with the USDA-ARS GRACEnet chamber-based trace gas flux measurement [20]. The chambers consisted of two parts: a chamber base and a vented sampling chamber head covered 
with reflective tape. The chamber base was made from white PVC pipe $(30 \mathrm{~cm}$ inside diameter, $6 \mathrm{~mm}$ thick, and $15 \mathrm{~cm}$ high). The chamber bases were driven $10 \mathrm{~cm}$ into the ground using a rectangular wooden block and a rubberized mallet, leaving a soil collar $5 \mathrm{~cm}$ above the ground in the center of the two middle rows of each plot.

Three tight-fitting butyl rubber septa were fitted to the top of the flux chamber head $(30 \mathrm{~cm}$ inside diameter, $6 \mathrm{~mm}$ thick, and $10 \mathrm{~cm}$ high). A 10-cm-long and 4.8-mm-inside-diameter PVC vent tube was inserted into the first butyl rubber cork on top of the flux chamber head to offset pressure differences between the inside and outside of the flux chamber during measurements. A thermometer was inserted into the second butyl rubber septum to measure temperature inside the flux chamber during measurements. The third butyl rubber septum was used as a sampling port into which a syringe needle was inserted during gas sampling. The chamber anchor bases were kept open at all times except during gas sampling.

During gas sampling, the chamber anchor bases were fitted with the tight-fitting vented chamber heads. At each gas sampling, the air inside the chamber was mixed by pumping air into the syringe and expelling the air three to five times. In 2013, gas sampling during the sorghum growing period started on May 15 and ended on October 12, whereas in 2014, sampling began on April 28 and ended on October 14. Gas samples were extracted at 0-, 15-, 30-, and 45-min time intervals. Sampling was typically restricted to between 9:00 a.m. and 1:00 p.m. to avoid large temperature fluctuations during gas collection periods. Immediately after extraction, the $25-\mathrm{mL}$ gas samples were transferred to $12-\mathrm{mL}$ pre-evacuated vials sealed with butyl rubber septa (Exetainer vial, Labco, Ltd., Lampeter, Ceredigion, UK) that over pressurized the system to ensure that in case of leakage, gas movement would be only out of the vials and not into the vials. We sampled every week and more intensively (twice/week) following fertilizer application and after rainfall events to cover most of the crop growth period. Sampling was reduced to once every 2 weeks when fluxes were observed to be at background levels. The 12-mL gas samples were transported to the laboratory for analyses. Gas concentrations were determined by gas chromatography (Model GC 14A; Shimadzu, Kyoto, Japan) equipped with a ${ }^{63} \mathrm{Ni}$ electron capture detector and a stainless steel column $(0.318-\mathrm{cm}$ diameter by $74.5-\mathrm{cm}$ long) with Poropak Q (80-100 mesh, Shimadzu, Kyoto, Japan).

\subsection{Surface Flux Calculations}

Surface fluxes were calculated using the following equation by [21]:

$$
f=\frac{\Delta C}{\Delta t} \times \frac{V}{A} \times \frac{m}{V_{m}}
$$

where:

$f=$ the flux rate of soil gas $\left(\mu \mathrm{gm}^{-2} \mathrm{~min}^{-1}\right)$

$\Delta C / \Delta t=$ change in $\mathrm{N}_{2} \mathrm{O}$ concentration inside the chamber during the measuring time $\Delta t$

$V=$ the head-space volume of the measuring chamber $\left(0.0109 \mathrm{~m}^{3}\right)$

$A=$ the surface area of the measuring chamber $\left(0.0706 \mathrm{~m}^{2}\right)$

$m=$ the molecular weight of $\mathrm{N}_{2} \mathrm{O}\left(44 \mathrm{gmol}^{-1}\right)$

$V_{m}=$ the molar volume of gas $\left(\mathrm{m}^{3} \mathrm{~mol}^{-1}\right)$

\subsection{Cumulative Nitrous Oxide Calculations}

The average $\mathrm{N}_{2} \mathrm{O}$ flux for each treatment was the arithmetic means of four replications of each treatment. Total cumulative $\mathrm{N}_{2} \mathrm{O}$ fluxes were calculated by plotting daily fluxes through time, interpolating linearly between them and integrating the area under the curve, which in effect assumes that fluxes changed linearly between sampling dates.

$$
\text { Cumulative } \mathrm{N}_{2} \mathrm{O}\left(\mathrm{g} \cdot \mathrm{N} \cdot \mathrm{ha}^{-1}\right)=\sum_{i=1}^{n} \frac{\left(X_{i}+X_{i+1}\right)}{2}\left(t_{i+1}-t_{i}\right)
$$


where $X_{i}$ was the initial $\mathrm{N}_{2} \mathrm{O}-\mathrm{N}$ flux $\left(\mathrm{g} \cdot \mathrm{ha}^{-1} \cdot \mathrm{day}^{-1}\right)$ reading and $X_{i+1}$ was the next reading at times $t_{i}$ and $t_{i+1}$, respectively, and $n$ was the last $\mathrm{N}_{2} \mathrm{O}-\mathrm{N}$ flux estimated during the study period.

In addition, percentage emission factor (EF) was calculated according to the following equation (IPCC, 1997):

$\mathrm{EF}=[($ cumulative flux $($ fertilizer treatment $)-$ cumulative flux $($ control $)) /($ fertilizer applied $)] \times 100$

\subsection{Soil Properties, Analyses and Ancillary Measurements}

A week before planting, composite soil samples were taken from each plot to a depth of $30 \mathrm{~cm}$ with a hand probe ( $4.5 \mathrm{~cm}$ in internal diameter). Samples consisted of 12 to 15 individual cores mixed to form individual composite samples. The soil was analyzed for both physical and chemical properties. Analyses were conducted by the Kansas State University Soil Testing Laboratory. Soil texture was determined by hydrometer method with the addition of $\mathrm{Na}_{6} \mathrm{P}_{6} \mathrm{O}_{18}$ to break down complex $\mathrm{Ca}^{2+}$, $\mathrm{Al}^{3+}, \mathrm{Fe}^{3+}$, and other cations that bind clay and silt particles into aggregates. Soil $\mathrm{pH}$ was estimated using a 1:1 slurry method with a 10-g scoop of soil and $10 \mathrm{~mL}$ of deionized water. Mehlich-3 P was analyzed by the $\mathrm{HCl}$-ammonium fluoride extraction method [22]. The Walkley-Black procedure [23] was used to analyze organic matter with the aid of a hydrometer (Model 6026Q20, Thomas Scientific). Extractable (plant-available) $\mathrm{K}$ and $\mathrm{Na}$ were determined by the ammonium acetate $\left(1 \mathrm{~mol} \cdot \mathrm{L}^{-1}, \mathrm{pH} 7.0\right.$ ) extraction method. In addition, chloride was extracted by $\mathrm{CaNO}_{3}$ and analyzed by the mercury thiocyanate method. In addition, the turbidimetric method [24] was used to determine sulfate-S. Nitrate and ammonium were measured by an indophenol colorimetric reaction [25] after soil samples were extracted with $1 \mathrm{~mol} \cdot \mathrm{L}^{-1} \mathrm{KCl}$. The soil test results are presented in Table 3.

Table 3. Physical and chemical characteristics of soil from the study site at a depth of $30 \mathrm{~cm}$.

\begin{tabular}{cccc}
\hline Parameters & Units & 2012-2013 & 2013-2014 \\
\hline Sand & $\%$ & 15.0 & 17.0 \\
Silt & $\%$ & 53.0 & 50.0 \\
Clay & $\%$ & 32.0 & 33.0 \\
pH & & 7.79 & 6.90 \\
Mehlich-3 P & $\mathrm{mg} \cdot \mathrm{kg}^{-1}$ & 11.2 & 12.5 \\
$\mathrm{~K}$ & $\mathrm{mg} \cdot \mathrm{kg}^{-1}$ & 225 & 218 \\
$\mathrm{Na}$ & $\mathrm{mg} \cdot \mathrm{kg}^{-1}$ & 18.1 & 17.9 \\
$\mathrm{Cl}^{-}$ & $\mathrm{mg} \cdot \mathrm{kg}^{-1}$ & 8.80 & 8.10 \\
$\mathrm{SO}_{4}-\mathrm{S}$ & $\mathrm{mg} \cdot \mathrm{kg}^{-1}$ & 2.70 & 2.90 \\
Organic Matter & $\%$ & 3.14 & 2.99 \\
\hline
\end{tabular}

Another set of soil samples was collected at six locations within each plot from $0-5-\mathrm{cm}$ - and 5-15-cm-depth using a 19-mm ID soil core sampler (Oakfield Apparatus, Inc., Oakfield, WI, USA) during the $\mathrm{N}_{2} \mathrm{O}$ sampling period. Sampling locations were randomly selected from within the center $0.38 \mathrm{~m}$ of the inner row region, avoiding areas affected by obvious wheel traffic compaction. Cores from each depth were pooled for a given plot, homogenized, and refrigerated before analysis of each plot collected for the determination of mineral $\mathrm{NO}_{3}{ }^{-}-\mathrm{N}$ and $\mathrm{NH}_{4}{ }^{+}-\mathrm{N}$. A 25-g fresh soil subsample from each sample was extracted with $100 \mathrm{~mL} 2 \mathrm{M} \mathrm{KCl}$, filtered (Whatman no. 42), shaken at $300 \mathrm{rpm}$ for $60 \mathrm{~min}$ and then filtered. Soil mineral $\mathrm{N}$ concentrations $\left(\mathrm{NH}_{4}{ }^{-}-\mathrm{N}_{\text {and }} \mathrm{NO}_{3}{ }^{-}-\mathrm{N}\right)$ in the filtrate were determined colorimetrically with a TRAACS 800 Auto-Analyzer (Bran-Luebbe, Analyzing Technologies, Elmsford, NY, USA) by the Kansas State University Soil Testing Laboratory.

Surface water content $(0$ to $5 \mathrm{~cm})$ and soil and air temperature were measured at the time of each gas flux sampling event using a dielectric constant-measurement Hydra Probe soil sensor (POGO, Stevens Systems, Inc., Beaverton, OR, USA) and handheld digital thermometers (Fisher, Hampton, $\mathrm{NH}, \mathrm{USA}$ ), respectively. Soil water contents were determined on samples by weighing before and after samples were dried at $105^{\circ} \mathrm{C}$. 
Additional soil samples were collected for analysis of bulk density at two sampling dates in each year. Because soil bulk density was observed not to vary with time or treatment during the period of measurement, soil volumetric water data were converted to water-filled pore space (WFPS) using the average bulk density $\left(1.18 \mathrm{~g} \cdot \mathrm{cm}^{-3}\right)$ for the site. Therefore, WFPS was calculated using the following equation:

WFPS $=($ soil gravimetric water content $\times$ bulk density $) /[1-($ bulk density/particle density $)]$

In addition, three different indices of yield-scaled $\mathrm{N}_{2} \mathrm{O}$ emissions were calculated by dividing cumulative area-scaled emissions by (i) grain yield, (ii) grain $\mathrm{N}$ uptake, and (iii) total aboveground plant $\mathrm{N}$ uptake.

Daily precipitation and average air temperatures were obtained from the Kansas State University Digital Weather Library that collected data from weather station within $25 \mathrm{~m}$ of the experimental plots.

\subsection{Statistical Analyses}

General and mixed linear models (PROC GLM, PROC MIXED) (9.3 SAS Institute, Inc., Cary, NC) were utilized for the analyses. Data for aboveground CC biomass yields, $C$ accumulation of CC, $\mathrm{N}$ uptake of CC, yields of sorghum, and soil inorganic N content were analyzed using the GLM procedure of SAS (Version 9.1, SAS Institute and Cary, NC, USA). Data distribution normality was assessed by the Shapiro-Wilk test. A repeated measures ANOVA model was employed for parameters measured multiple times over the study year. In repeated-measures mixed models, block was included as a random effect, sampling date as the repeated factor, and treatments and their interaction as fixed effects using PROC MIXED in SAS (Version 9.1, SAS Institute, Cary, NC, USA). The best model for covariance was tested by stepwise inclusion of different covariance structures available in SAS. Based on lower Akaike information criterion and convergence, we chose Ante-dependence 1, which permits the variance among observations to vary over time. Ante-dependence was used because for our data, the times of measurement were common across units. Nitrous oxides emissions were estimated by linear interpolation between sampling dates. Linear correlations were carried out to determine relationships between gas fluxes and WFPS, $\mathrm{NH}_{4}{ }^{+}-\mathrm{N}$, and $\mathrm{NO}_{3}{ }^{-}-\mathrm{N}$. These correlation analyses were performed using the mean data of replicates for all treatments $(n=6)$ and all the dates when soil and $\mathrm{N}_{2} \mathrm{O}$ was sampled in $2013(\mathrm{n}=22), 2014(\mathrm{n}=26)$ or the entire cropping cycle $(2013$ and 2014; $\mathrm{n}=48)$. Treatment means were separated via pairwise t-tests. Statistical significance was evaluated at $p<0.05$, unless noted otherwise.

\section{Results}

\subsection{Climatic Conditions}

Climatic conditions varied among the growing seasons from 2012-2014 (Table 4). Mean maximum temperature during the growing season in 2012 was $28.6{ }^{\circ} \mathrm{C}$. However, $37.4{ }^{\circ} \mathrm{C}$ was recorded in July, the hottest month during the growing season. In 2013, average maximum air temperature during the sampling period was below $30^{\circ} \mathrm{C}$, except in July, when the maximum air temperature exceeded $32.1^{\circ} \mathrm{C}$. However, in 2014 , maximum air temperature in August was above $30^{\circ} \mathrm{C}$. Maximum soil temperature ranged from $14.6-27.6^{\circ} \mathrm{C}, 12.0-25.5^{\circ} \mathrm{C}$, and $13.4-29.3^{\circ} \mathrm{C}$ in 2012,2013 , and 2014, respectively. In addition, rainfall amounts of $338 \mathrm{~mm}, 550 \mathrm{~mm}$, and $589 \mathrm{~mm}$ were recorded in 2012, 2013, and 2014, respectively. In 2012, mean solar radiation was $20.7 \mathrm{MJ} / \mathrm{m}^{-2}$, and was $18.4 \mathrm{MJ} / \mathrm{m}^{-2}$ in 2013. While in 2014, mean solar radiation recorded was $18.9 \mathrm{MJ} / \mathrm{m}^{-2}$. 
Table 4. Climatic conditions (maximum air temperature, maximum soil temperature, rainfall, and solar radiation) during 2012-2014 growing seasons.

\begin{tabular}{|c|c|c|c|c|c|c|c|c|c|c|c|c|}
\hline \multirow[b]{2}{*}{ Month } & \multicolumn{4}{|c|}{2012} & \multicolumn{4}{|c|}{2013} & \multicolumn{4}{|c|}{2014} \\
\hline & $\begin{array}{l}\text { Max Air } \\
\text { Temp }\end{array}$ & $\begin{array}{l}\text { Max. Soil } \\
\text { Temp }\end{array}$ & Rainfall & $\begin{array}{c}\text { Solar } \\
\text { Radiation }\end{array}$ & $\begin{array}{c}\text { Max Air } \\
\text { Temp }\end{array}$ & $\begin{array}{l}\text { Max. Soil } \\
\text { Temp }\end{array}$ & Rainfall & $\begin{array}{c}\text { Solar } \\
\text { Radiation }\end{array}$ & $\begin{array}{c}\text { Max Air } \\
\text { Temp }\end{array}$ & $\begin{array}{l}\text { Max. Soil } \\
\text { Temp }\end{array}$ & Rainfall & $\begin{array}{c}\text { Solar } \\
\text { Radiation }\end{array}$ \\
\hline & ${ }^{\circ} \mathrm{C}$ & ${ }^{\circ} \mathrm{C}$ & $\mathrm{mm}$ & Total MJ $/ \mathrm{m}^{2}$ & ${ }^{\circ} \mathrm{C}$ & ${ }^{\circ} \mathrm{C}$ & $\mathrm{mm}$ & Total $\mathrm{MJ} / \mathrm{m}^{2}$ & ${ }^{\circ} \mathrm{C}$ & ${ }^{\circ} \mathrm{C}$ & $\mathrm{mm}$ & Total MJ $/ \mathrm{m}^{2}$ \\
\hline April & 22.3 & 14.6 & 49.7 & 19.2 & 16.3 & 12 & 87.6 & 16.1 & 19.7 & 13.4 & 105.4 & 16.4 \\
\hline May & 28.6 & 20.1 & 27.2 & 24.3 & 23.8 & 17.9 & 99 & 18.8 & 26 & 20.9 & 49 & 21.6 \\
\hline June & 32.9 & 23.4 & 83.8 & 26.1 & 30.0 & 24.5 & 88.4 & 23.0 & 29.3 & 25.1 & 224.3 & 21.3 \\
\hline July & 37.4 & 27.6 & 14.7 & 24.9 & 31.1 & 26.0 & 36.8 & 20.2 & 31.5 & 28.1 & 17.1 & 24.0 \\
\hline August & 32.3 & 23.5 & 106.9 & 20.8 & 30.6 & 25.5 & 23.8 & 19.5 & 33.0 & 29.3 & 101.3 & 20.2 \\
\hline October & 20.0 & 14.1 & 14.2 & 12.7 & 20.1 & 16.7 & 109.9 & 12.5 & 21.8 & 17.6 & 62.5 & 13.1 \\
\hline
\end{tabular}

Source: Kansas State University Weather Library. 


\subsection{Aboveground Biomass, Carbon, and Nitrogen Uptake by Cover Crops}

Aboveground biomass, $\mathrm{C}$ accumulation, $\mathrm{N}$ uptake, and $\mathrm{C}: \mathrm{N}$ ratio of $\mathrm{CC}$ were all affected by year and cropping system $(p<0.05)$ (Table 5 and Figure 1). Among the cover crops, PG had the greatest aboveground biomass compared to cowpea and sunn hemp in 2012 when the rotation was established. While sunn hemp produced the greatest amount of aboveground biomass in 2013, followed by pigeon pea and then cowpea (Figure 1a).

Table 5. Significance of main effects of year, cropping system, and their interactions from the analysis of variance (ANOVA) for the effect of cover crops growth during 2012 and 2013 growing seasons.

\begin{tabular}{cccc}
\hline Parameter & Year $(\mathbf{Y})$ & Cropping System & Interaction \\
\hline Cover crop aboveground biomass & $* *$ & $* *$ & $*$ \\
Cover crop aboveground C accumulation & $*$ & $* *$ & $*$ \\
Cover crop aboveground N uptake & $*$ & $* *$ & $* *$ \\
Carbon-to-nitrogen ratio & $*$ & $*$ &
\end{tabular}

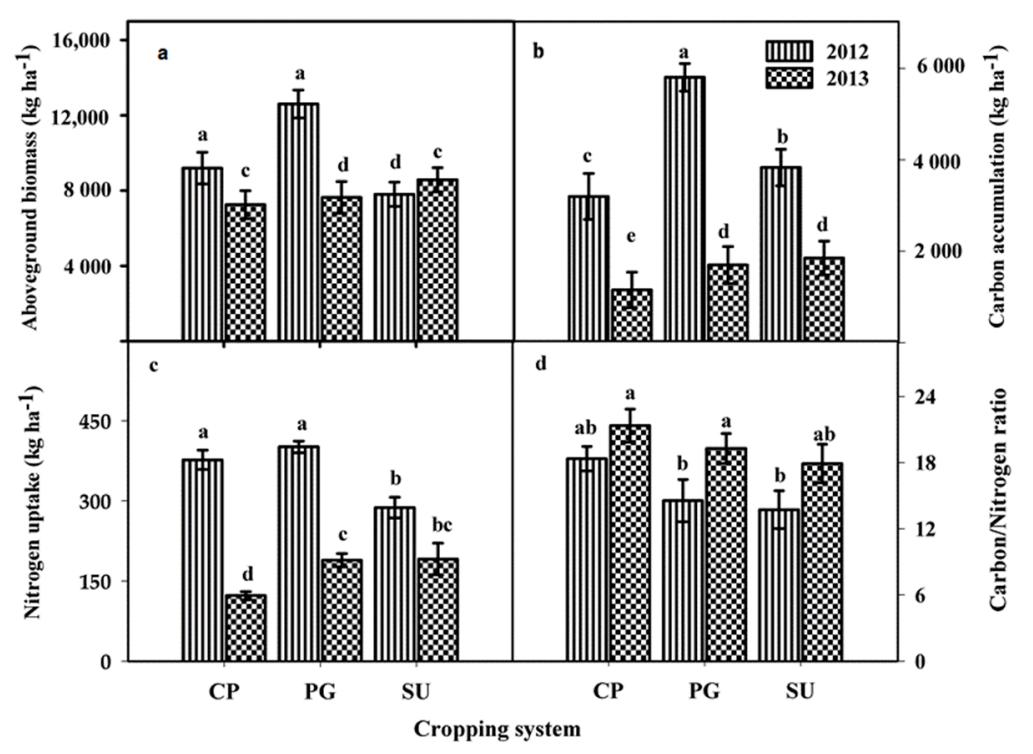

Figure 1. Effects of year by cropping system on (a) aboveground biomass, (b) carbon accumulation, (c) nitrogen uptake, and (d) carbon-to-nitrogen ratio of cover crops. Error bars represent standard error of means. Letter on bars describe the significance of the treatments. Bars with same letter are not significantly different based on their standard errors.

Aboveground C accumulation was significantly $(p<0.05)$ greater for PG followed by SU and CP in 2012. In 2013, CP had the lowest $C$ accumulation, but $C$ accumulation was significantly higher for PG and SU (Figure 1b). In 2012, N uptake was similar for cowpea and pigeon pea, but was significantly lower for SU. On the other hand, CP had the lowest N uptake when compared to PG and SU in 2013 (Figure 1c). Carbon-to-nitrogen ratio was less than 20 for all cover crops in both years, and the ranking was similar in both years, with CP $>$ PG $>$ SU (Figure 1d).

\subsection{Soil Inorganic Nitrogen}

Soil inorganic $\mathrm{N}$ was affected by day of sampling and cropping systems $(p<0.05)$ (Table 5 and Figure 2). Soil inorganic $\mathrm{N}\left(\mathrm{NO}_{3}{ }^{-}-\mathrm{N}\right.$ and $\left.\mathrm{NH}_{4}{ }^{+}-\mathrm{N}\right)$ at both $0-5-\mathrm{cm}$ and 5-15-cm depths in 2013 and 2014 was less than $10 \mu \mathrm{g} \mathrm{N} \mathrm{g}^{-1}$ soil at the beginning of each growing season and start of gas sampling (Figure 2). Maximum soil inorganic $\mathrm{N}$ concentrations were observed 11 to $15 \mathrm{~d}$ after $\mathrm{N}$ application in 
2013 and 2014. Generally, more soil inorganic N was recorded in the cropping system with $90 \mathrm{~N}$ and $180 \mathrm{~N}$ in both years compare to CP, PG, and SU (Figure 2). Soil inorganic $\mathrm{N}\left(\mathrm{NO}_{3}{ }^{-} \mathrm{N}\right)$ of $48.69 \mu \mathrm{g} \mathrm{N} \mathrm{g}{ }^{-1}$ and $30.33 \mu \mathrm{g} \mathrm{N} \mathrm{g}{ }^{-1}$ at the soil depth of 0-5 $\mathrm{cm}$ were recorded in 2013 in the cropping system with $180 \mathrm{~N}$ when soil were sampled at DOY 168 and 181, respectively (Figure 2). While in 2014, for the same cropping system with $180 \mathrm{~N}$, on DOY (154 and 188), soil inorganic $\mathrm{N}\left(\mathrm{NO}_{3}{ }^{-}-\mathrm{N}\right)$ were $111.94 \mu \mathrm{g} \mathrm{N} \mathrm{g}{ }^{-1}$ and $96.66 \mu \mathrm{g} \mathrm{N} \mathrm{g}^{-1}$, respectively at soil depth of $0-5 \mathrm{~cm}$ (Figure 2). In both years, at soil depth of $5-15 \mathrm{~cm}$, soil inorganic $\mathrm{N}\left(\mathrm{NO}_{3}{ }^{-}-\mathrm{N}\right)$ values were less than $40 \mu \mathrm{g} \mathrm{N} \mathrm{g}^{-1}$ irrespective of the sampling date and cropping system (Figure 2). For soil inorganic $\mathrm{N}\left(\mathrm{NH}_{4}{ }^{+}-\mathrm{N}\right)$, in 2013 at a depth of $0-5 \mathrm{~cm}$, on DOY (168), cropping system with $90 \mathrm{~N}$ and $180 \mathrm{~N}$ recorded $34.67 \mu \mathrm{g} \mathrm{N} \mathrm{g}^{-1}$ and $37.21 \mu \mathrm{g} \mathrm{N} \mathrm{g}{ }^{-1}$, respectively. However, in 2014, both at $0-5$ and 5-15 cm soil depth, soil inorganic $\mathrm{N}\left(\mathrm{NH}_{4}{ }^{+}-\mathrm{N}\right)$ values were less than $20 \mu \mathrm{g} \mathrm{N} \mathrm{g}^{-1}$ for all the cropping systems (Figure 2).
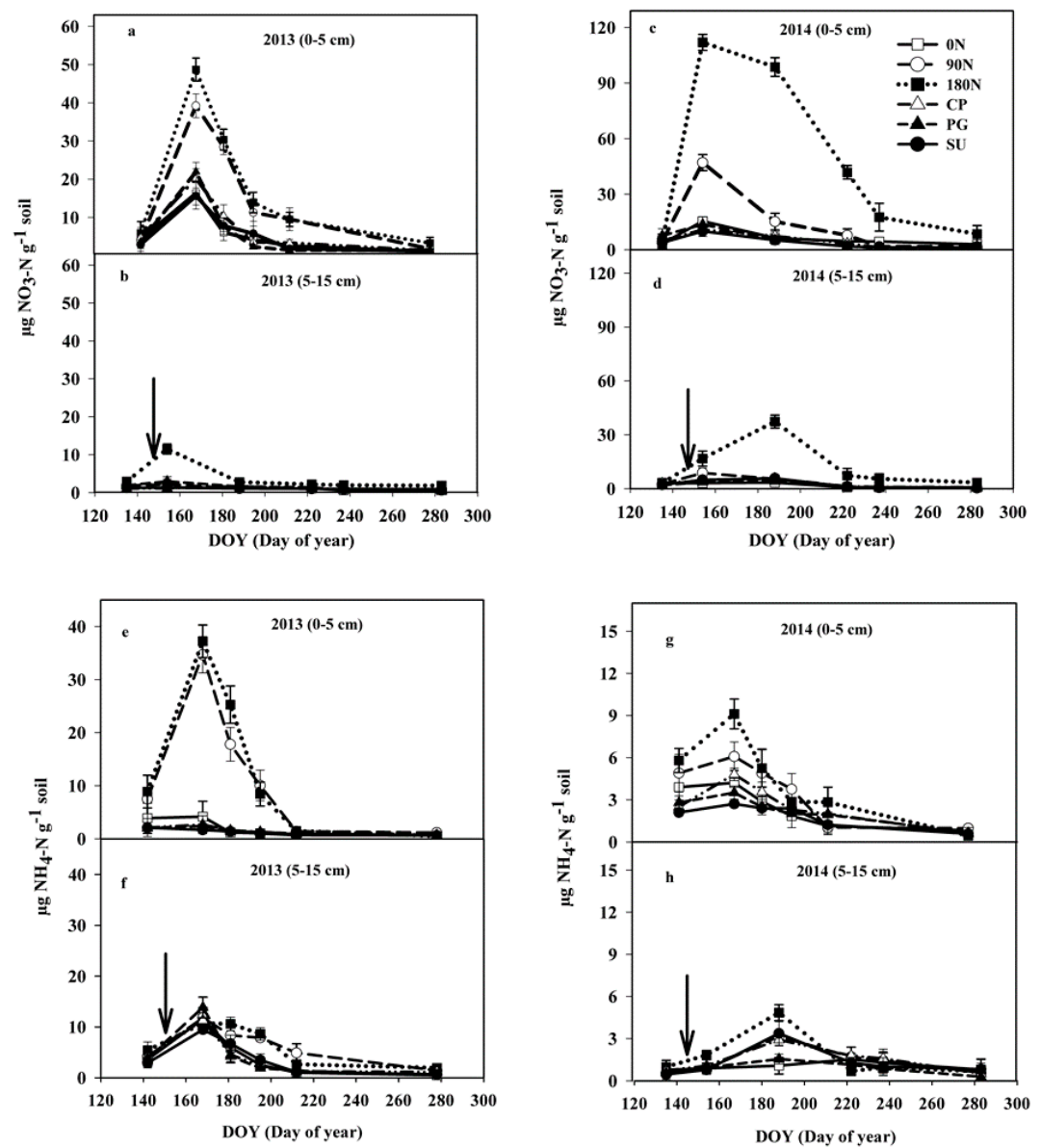

Figure 2. Effects of date of sampling and cropping systems on (a) $\mathrm{NO}_{3}{ }^{-}-\mathrm{N}$ at $0-5-\mathrm{cm}$ depth in 2013; (b) $\mathrm{NO}_{3}{ }^{-}-\mathrm{N}$ at $5-15-\mathrm{cm}$ depth in 2013 (c) $\mathrm{NO}_{3}{ }^{-}-\mathrm{N}$ at $0-5-\mathrm{cm}$ depth in 2014; (d) $\mathrm{NO}_{3}{ }^{-}-\mathrm{N}$ at $5-15-\mathrm{cm}$ depth in 2014; (e) $\mathrm{NH}_{4}{ }^{+}$-Nat 0-5-cm depth in 2013 (f) $\mathrm{NH}_{4}{ }^{+}-\mathrm{N}$ at 5-15-cm depth in 2013; (g) $\mathrm{NH}_{4}{ }^{+}-\mathrm{N}$ at $0-5-\mathrm{cm}$ depth in 2014, and (h) $\mathrm{NH}_{4}{ }^{+}-\mathrm{N}$ at 5-15-cm depth in 2014. Arrows show the fertilizer application dates (7 June 2013 and 4 June 2014). Error bars on symbols represent standard error of treatment means for that sample date.

\subsection{Precipitation, Water-Filled Pore Space, and Daily Nitrous Oxide Emissions}

Precipitation influenced water filled space and daily nitrous oxide emissions in 2013 and 2014 (Figure 3). Water-filled pore space increased to $68 \%$ on day of year (DOY 157) after several rainfall events totaling $46 \mathrm{~mm}$. During the gas-sampling period, the lowest WFPS was recorded on DOY 251 as a result of less than $2 \mathrm{~mm}$ of rainfall from DOY 227 to DOY 251 (Figure 3a). The daily emissions of $\mathrm{N}_{2} \mathrm{O}-\mathrm{N}$ differed significantly among the sampling dates, which was clearly related to precipitation 
events and WFPS (Table 6 and Figure 3). Emissions increased dramatically on DOY 175 in 2013 because a precipitation event of $27.2 \mathrm{~mm}$ immediately preceding that sample date resulted in WFPS of $89.5 \%$ (Figure $3 \mathrm{a}, \mathrm{b}$ ). Among the cropping systems, application of $180 \mathrm{~N}$ usually had the greatest daily emission followed by $90 \mathrm{~N}$, which was followed by cropping system with CP throughout the sampling period $(p<0.05)$. The cropping systems with the smallest daily and cumulative emissions were when $\mathrm{N}$ was not applied $(0 \mathrm{~N})$, plots with PG and SU (Figure 3b). The largest precipitation event during the sampling period was at DOY 258 with $70.4 \mathrm{~mm}$ and WFSP of $99.9 \%$, but the precipitation event did not influence amount of emission (Figure 3a,b).
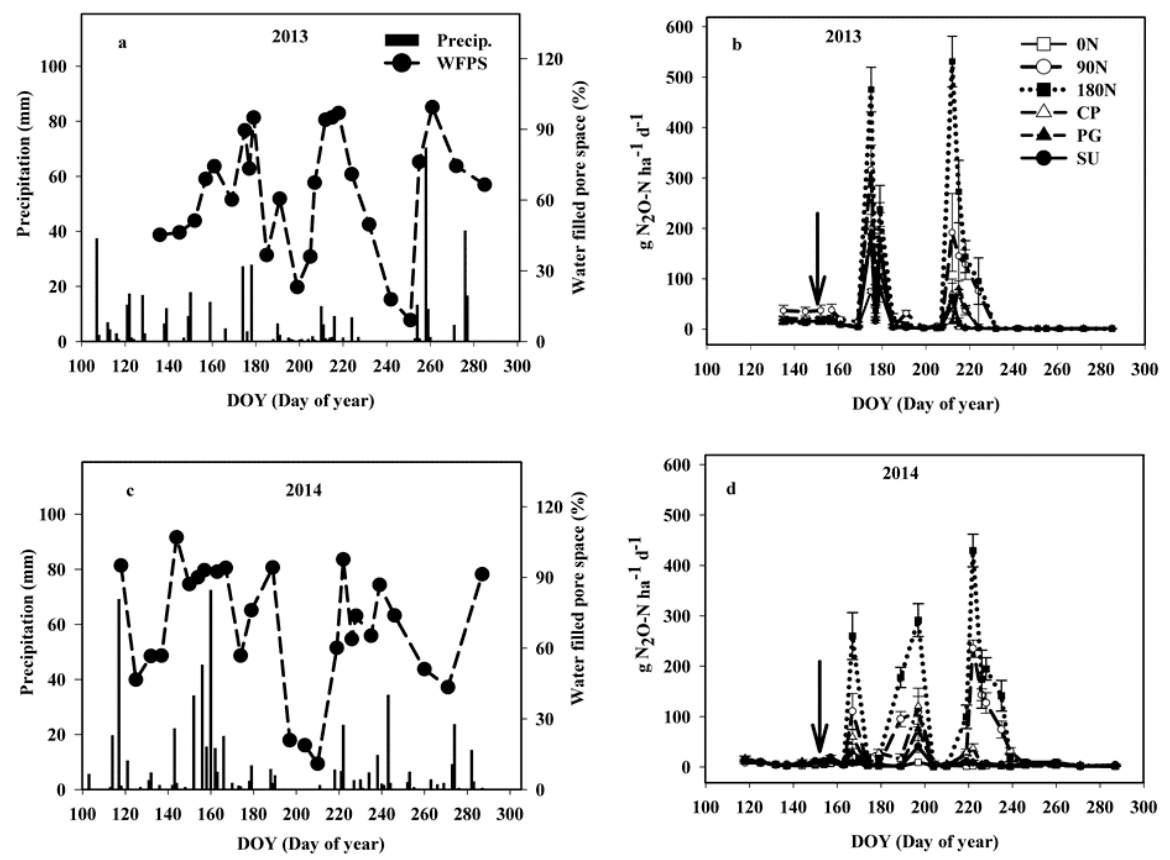

Figure 3. Daily (a) precipitation and water-filled pore space (WFPS) in 2013 , (b) $\mathrm{N}_{2} \mathrm{O}-\mathrm{N}$ emissions in 2013, (c) daily precipitation, and water-filled pore space (WFPS) in 2014, and (d) $\mathrm{N}_{2} \mathrm{O}-\mathrm{N}$ emissions in 2014. Arrows show date of fertilizer application (7 June 2013 and 4 June 2014). Error bars on symbols represent standard error of treatment means for that sample date.

Table 6. Significance of main effects of cropping system (CS), date of sampling (DOS), and their interactions from the analysis of variance (ANOVA) on daily nitrous oxide emissions, cumulative nitrous oxide emissions, nitrate-N, and ammonium-N during 2013 and 2014 growing season.

\begin{tabular}{ccccccc}
\hline & \multicolumn{3}{c}{2013} & \multicolumn{3}{c}{2014} \\
\hline Parameter $\downarrow$ Treatments $\rightarrow$ & CS & DOS & CS $\times$ DOS & CS & DOS & CS $\times$ DOS \\
\hline Daily $\mathrm{N}_{2} \mathrm{O}$ emissions & $* * *$ & $* *$ & $* *$ & $* *$ & $* * *$ & $* *$ \\
Cumulative $\mathrm{N}_{2} \mathrm{O}$ emissions & $* * *$ & $* * *$ & $* * *$ & $* * *$ & $* * *$ & $* * *$ \\
Nitrate-N $(0-5 \mathrm{~cm})$ & $* * *$ & $* *$ & $* * *$ & $* *$ & $* *$ & $*$ \\
Nitrate-N $(5-15 \mathrm{~cm})$ & $* *$ & $* * *$ & $* * *$ & $* *$ & $* * *$ & $* *$ \\
Ammonium-N $(0-5 \mathrm{~cm})$ & $* * *$ & $*$ & $* *$ & $* * *$ & $*$ & $* *$ \\
Ammonium-N $(5-15 \mathrm{~cm})$ & $*$ & $* * *$ & $*$ & $*$ & $* * *$ & $* *$ \\
\hline
\end{tabular}

$\mathrm{N}_{2} \mathrm{O}$, Nitrous oxide, ${ }^{*}, * *$, and ${ }^{* * *}$ are significant at the $p<0.05,0.01$, and 0.001 level, respectively.

In 2014, WFPS at DOY 118 was 95\% due to total precipitation amount of $69 \mathrm{~mm}$ on DOY 117. WFPS was generally greater than 50\% in 2014, except on DOY 125 (46\%), DOY 197 (20\%), DOY 204 $(18 \%)$, DOY $210(10 \%)$, and DOY $271(43 \%)$ due to precipitation amount less than $5.0 \mathrm{~mm}$ (Figure 3c). Emissions in 2014 were generally less than in 2013 (often $<30 \mathrm{~g} \cdot \mathrm{N} \cdot \mathrm{ha}^{-1} \cdot \mathrm{d}^{-1}$ ) (Figure 3d). Within the season, $\mathrm{N}_{2} \mathrm{O}$ emissions were low from late April through early June, then increased considerably on 
DOY 167, with total precipitation of $21.0 \mathrm{~mm}$ and WFPS of $94 \%$ (Figure 3c,d), especially with cropping systems applied with $90 \mathrm{~N}$ and $180 \mathrm{~N}$.

Emissions of $\mathrm{N}_{2} \mathrm{O}$ were affected by $\mathrm{N}$ application, amount of rainfall and soil $\mathrm{N}$ available from the CC residues. In 2014, little precipitation was received from early July through early August, resulting in low WFPS and thus low $\mathrm{N}_{2} \mathrm{O}$ emissions. The most notable emissions were recorded in cropping system with $90 \mathrm{~N}$ and $180 \mathrm{~N}$, which peaked in mid-August following closely spaced rainfall events (Figure 3c,d). Season-long cumulative emissions in 2014 followed a pattern similar to that observed in 2013, but cropping system including the PG had greater emissions than the $0 \mathrm{~N}$.

\subsection{Growing Season Cumulative Nitrous Oxide Emissions}

A significant $(p<0.05)$ treatment effect was observed on cumulative $\mathrm{N}_{2} \mathrm{O}$ emissions at the end of the sampling period. The values for cumulative emissions for each treatment closely reflected daily emissions. In $2013,180 \mathrm{~N}$ had the greatest cumulative (annual) emissions, followed by $90 \mathrm{~N}$ and CP (Figure 4a). No difference was detected among cropping systems with ON, PG, and SU (Figure 4a). Similarly, in 2014, 180N had the greatest annual emission compared with cropping system with $90 \mathrm{~N}$ and $\mathrm{CP}$ (Figure $4 \mathrm{~b}$ ). However, $\mathrm{ON}$ and $\mathrm{SU}$ had the lowest cumulative nitrous oxide emissions, but was significantly higher in cropping system with PG (Figure 4b).

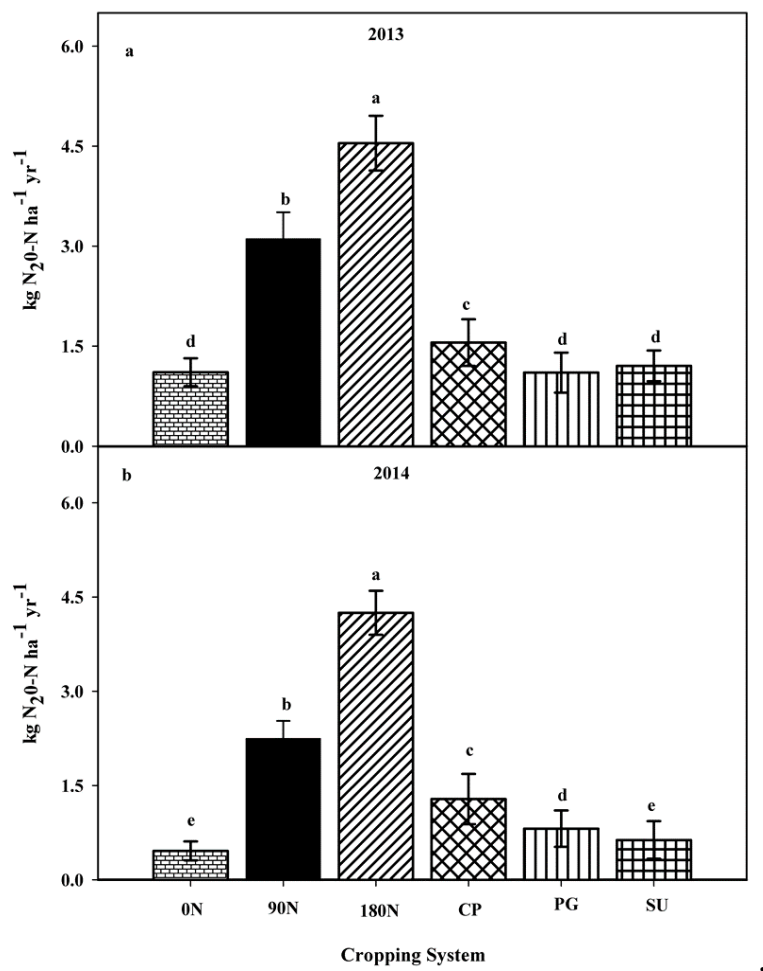

Figure 4. Cumulative $\mathrm{N}_{2} \mathrm{O}-\mathrm{N}$ emissions of different cropping systems in (a) 2013 and (b) 2014 growing seasons. Error bars represent standard error of means. Letter on bars describe the significance of the treatments. Bars with same letter are not significantly different based on their standard errors.

\subsection{Sorghum Grain Yield Following Cover Crops and Specific Nitrous Oxide Emissions}

Grain yield, $\mathrm{N}$ uptake, grain $\mathrm{N}$ uptake, total $\mathrm{N}$ uptake, per unit of grain yield, per unit of grain $\mathrm{N}$ uptake, and per unit of total $\mathrm{N}$ were significant $(p<0.05)$ among the cropping systems with application of $\mathrm{N}$ only or inclusion of CC only in 2013. Grain yield ranged from 4540 to $7581 \mathrm{~kg} \cdot \mathrm{ha}^{-1}$ (Table 7). Percentage increase in grain yield with inclusion of SU, PG, and CP in the cropping system over $0 \mathrm{~N}$ was $12 \%, 27 \%$, and $29 \%$, respectively. For $\mathrm{N}_{2} \mathrm{O}-\mathrm{N}$ emission per unit of grain yield, cropping system with $0 \mathrm{~N}$, $\mathrm{CP}, \mathrm{PG}$, and SU obtained lower values, but were significantly higher for $90 \mathrm{~N}$ and $180 \mathrm{~N}$. Nitrous oxides 
emission per unit grain $\mathrm{N}$ uptake was much higher with cropping system with $180 \mathrm{~N}$ when compared to other cropping systems. The lowest $\mathrm{N}_{2} \mathrm{O}-\mathrm{N}$ emission per unit grain $\mathrm{N}$ uptake was observed in cropping system with PG. Among all the cropping systems, application of $180 \mathrm{~N}$ had the highest $\mathrm{N}_{2} \mathrm{O}-\mathrm{N}$ emission per unit total $\mathrm{N}$ uptake compared to other cropping systems (Table 7). Emission factor in the cropping system with $90 \mathrm{~N}$ was lower, but significantly higher in cropping system with $180 \mathrm{~N}$.

Table 7. Effects of $\mathrm{N}$ rate and cropping systems on cumulative $\mathrm{N}_{2} \mathrm{O}-\mathrm{N}$ emissions, grain yield, $\mathrm{N}$ uptake and $\mathrm{N}_{2} \mathrm{O}$ emission per unit of grain $\mathrm{N}$, and total $\mathrm{N}$ uptake of grain sorghum in 2013 growing season.

\begin{tabular}{|c|c|c|c|c|c|c|c|c|}
\hline \multirow[b]{2}{*}{$\begin{array}{l}\text { Cropping } \\
\text { System }^{+}\end{array}$} & \multirow[b]{2}{*}{$\begin{array}{l}\text { Grain } \\
\text { Yield }\end{array}$} & \multirow[b]{2}{*}{$\begin{array}{c}\mathrm{N} \\
\text { Uptake }\end{array}$} & \multirow[b]{2}{*}{$\begin{array}{l}\text { Grain N } \\
\text { Uptake }\end{array}$} & \multicolumn{5}{|c|}{$\mathrm{N}_{2} \mathrm{O}-\mathrm{N}$ Emissions } \\
\hline & & & & $\begin{array}{l}\text { Total N } \\
\text { Uptake }\end{array}$ & $\begin{array}{l}\text { Per Unit of } \\
\text { Grain Yield }\end{array}$ & $\begin{array}{l}\text { Per Unit Grain } \\
\text { N Uptake }\end{array}$ & $\begin{array}{l}\text { Per Unit Total } \\
\text { N Uptake }\end{array}$ & $\begin{array}{c}\text { Emission } \\
\text { Factor } \ddagger\end{array}$ \\
\hline & \multicolumn{4}{|c|}{$\mathrm{kg} \cdot \mathrm{ha}^{-1}$} & $\mathrm{~g} \cdot \mathrm{N} \cdot \mathrm{Mg}^{-1}$ & \multicolumn{2}{|c|}{$\mathrm{g} \cdot \mathrm{N} \cdot \mathrm{kg}^{-1}$} & $\%$ \\
\hline $0 \mathrm{~N}$ & $4540 \mathrm{~d}$ & $36.3 b$ & $34.6 c$ & $70.9 \mathrm{c}$ & $246.3 c$ & $32.2 \mathrm{c}$ & $15.6 c$ & \\
\hline $90 \mathrm{~N}$ & 7134ab & $56.1 \mathrm{ab}$ & $55.8 \mathrm{ab}$ & $111.9 \mathrm{ab}$ & $438 b$ & $50.1 b$ & $25.2 b$ & 1.91 \\
\hline $180 \mathrm{~N}$ & 7581a & $61.1 \mathrm{a}$ & $62.0 \mathrm{a}$ & $123.2 \mathrm{a}$ & $598 \mathrm{a}$ & $81.4 \mathrm{a}$ & $40.6 a$ & 2.22 \\
\hline $\mathrm{CP}$ & $6439 \mathrm{abc}$ & $44.3 \mathrm{ab}$ & $46.0 \mathrm{bc}$ & $90.3 \mathrm{abc}$ & $243.0 \mathrm{c}$ & $30.2 \mathrm{c}$ & $16.8 \mathrm{bc}$ & \\
\hline PG & $6228 \mathrm{bc}$ & $43.9 \mathrm{ab}$ & $55.9 \mathrm{ab}$ & $99.8 \mathrm{abc}$ & $178.1 \mathrm{c}$ & $19.8 \mathrm{~d}$ & $11.1 \mathrm{c}$ & \\
\hline SU & 5181cd & $38.6 a b$ & $42.2 b c$ & $80.8 b c$ & $231.7 \mathrm{c}$ & $28.6 c$ & $14.9 \mathrm{c}$ & \\
\hline
\end{tabular}

${ }^{\dagger} 0 \mathrm{~N}, 90 \mathrm{~N}$, and $180 \mathrm{~N}=0,90$, and $80 \mathrm{~kg} \mathrm{~N} \mathrm{ha}^{-1}$ applied to sorghum crop at planting; $\mathrm{CP}, \mathrm{PG}$, and $\mathrm{SU}=\mathrm{Cowpea}$, Pigeon pea, or Sunn hemp cover crops planted between wheat harvest and sorghum planting. ${ }^{\ddagger}$ Estimate of percent of fertilizer $\mathrm{N}$ lost via $\mathrm{N}_{2} \mathrm{O}$ emissions. Values within a column followed by the same letter are not significantly different.

There were significant $(p<0.05)$ differences among the cropping systems for all the variables estimated (Table 8) in 2014. Grain yield was similar for all the cropping systems, except for $0 \mathrm{~N}$, which had a lower value. Percentage increase in grain yield with inclusion of SU, PG, and CP in the cropping system over $0 \mathrm{~N}$ was $31 \%, 33 \%$, and $32 \%$, respectively. The results showed that $\mathrm{N}$ uptake, grain $\mathrm{N}$ uptake, and total $\mathrm{N}$ uptake were similar among cropping system that had CP, PG, and SU. However, $\mathrm{N}_{2} \mathrm{O}-\mathrm{N}$ emissions per unit of grain $\mathrm{N}$ were not statistically different between cropping system with CC and $0 \mathrm{~N}$. However, the cropping system with $\mathrm{SU}$ had $\mathrm{N}_{2} \mathrm{O}-\mathrm{N}$ emissions per unit of grain $\mathrm{N}$ similar to $0 \mathrm{~N}$. Although $\mathrm{N}_{2} \mathrm{O}-\mathrm{N}$ emissions per unit of total $\mathrm{N}$ uptake were not statistically different between PG, SU, and $0 \mathrm{~N}$, the Emission factor was greater with applications of $180 \mathrm{~N}$ than $90 \mathrm{~N}$.

Table 8. Effects of $\mathrm{N}$ rate and cropping systems on cumulative $\mathrm{N}_{2} \mathrm{O}-\mathrm{N}$ emissions, grain yield, $\mathrm{N}$ uptake and $\mathrm{N}_{2} \mathrm{O}$ emissions per unit of grain $\mathrm{N}$, and total $\mathrm{N}$ uptake of grain sorghum in 2014 growing season.

\begin{tabular}{|c|c|c|c|c|c|c|c|c|}
\hline \multirow[b]{2}{*}{$\begin{array}{l}\text { Cropping } \\
\text { System }\end{array}$} & \multirow[b]{2}{*}{$\begin{array}{l}\text { Grain } \\
\text { Yield }\end{array}$} & \multirow[b]{2}{*}{$\begin{array}{c}\mathrm{N} \\
\text { Uptake }\end{array}$} & \multirow[b]{2}{*}{$\begin{array}{l}\text { Grain N } \\
\text { Uptake }\end{array}$} & \multicolumn{5}{|c|}{$\mathrm{N}_{2} \mathrm{O}-\mathrm{N}$ emissions } \\
\hline & & & & $\begin{array}{l}\text { Total N } \\
\text { Uptake }\end{array}$ & $\begin{array}{l}\text { Per Unit of } \\
\text { Grain Yield }\end{array}$ & $\begin{array}{l}\text { Per Unit Grain } \\
\text { N Uptake }\end{array}$ & $\begin{array}{l}\text { Per Unit Total } \\
\text { N Uptake }\end{array}$ & $\begin{array}{c}\text { Emission } \\
\text { Factor } \ddagger\end{array}$ \\
\hline & \multicolumn{4}{|c|}{$\mathrm{kg} \cdot \mathrm{ha}^{-1}$} & $\mathrm{~g} \cdot \mathrm{N} \cdot \mathrm{Mg}^{-1}$ & \multicolumn{2}{|c|}{$\mathrm{g} \cdot \mathrm{N} \cdot \mathrm{kg}^{-1}$} & $\%$ \\
\hline $0 \mathrm{~N}$ & $4197 \mathrm{~b}$ & $21.8 \mathrm{c}$ & $31.5 c$ & $53.3 c$ & $109.3 d$ & $20.1 b$ & $11.9 \mathrm{~cd}$ & - \\
\hline $90 \mathrm{~N}$ & $6853 a$ & $46.6 c$ & $64.4 \mathrm{ab}$ & $110.9 a$ & $325.8 b$ & $69.2 a$ & $40.2 \mathrm{a}$ & 1.98 \\
\hline $180 \mathrm{~N}$ & $7754 a$ & $38.6 a b$ & $84.1 \mathrm{a}$ & $122.7 \mathrm{a}$ & $571.3 a$ & $54.2 \mathrm{ab}$ & $37.1 \mathrm{a}$ & 2.11 \\
\hline $\mathrm{CP}$ & $6176 a$ & $24.5 c$ & $50.7 b c$ & $75.2 b$ & $207.3 \mathrm{c}$ & $44.3 \mathrm{ab}$ & $29.9 b$ & - \\
\hline PG & $6238 a$ & $29.1 b$ & $41.9 \mathrm{c}$ & $71.0 \mathrm{bc}$ & 131.1cd & $30.7 \mathrm{~b}$ & $18.1 \mathrm{c}$ & - \\
\hline SU & $6049 a$ & $30.1 b c$ & $47.8 \mathrm{bc}$ & $77.9 b$ & $105.5 \mathrm{~d}$ & $17.0 \mathrm{~b}$ & $10.4 \mathrm{~d}$ & - \\
\hline
\end{tabular}

${ }^{+} 0 \mathrm{~N}, 90 \mathrm{~N}$, and $180 \mathrm{~N}=0,90$, and $80 \mathrm{~kg} \mathrm{~N} \mathrm{ha}^{-1}$ applied to sorghum crop at planting; CP, $\mathrm{PG}$, and $\mathrm{SU}=\mathrm{Cowpea}$, Pigeon

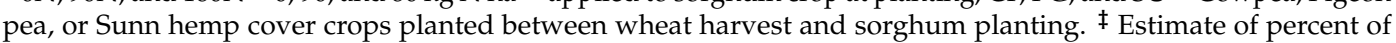
fertilizer $\mathrm{N}$ lost via $\mathrm{N}_{2} \mathrm{O}$ emissions. Values within a column followed by the same letter are not significantly different.

Nitrous oxide emissions significantly correlated with soil temperature in $2013(p<0.05, \mathrm{n}=22$, $\mathrm{r}=0.57)$ and $2014(p<0.05, \mathrm{n}=26, \mathrm{r}=0.63)$. In addition, daily $\mathrm{N}_{2} \mathrm{O}$ emissions significantly correlated with $\mathrm{NH}_{4}{ }^{+}$topsoil content $(p<0.05, \mathrm{n}=22, \mathrm{r}=0.81)$ in 2013 and $(p<0.05, \mathrm{n}=26, \mathrm{r}=0.76)$ in 2014 . During the entire cropping cycle (2013 and 2014), $\mathrm{N}_{2} \mathrm{O}$ fluxes significantly correlated with WFPS $(p<0.05, \mathrm{n}=48, \mathrm{r}=0.65), \mathrm{NO}_{3}^{-}(p<0.05, \mathrm{n}=48, \mathrm{r}=0.60)$, and $\mathrm{NH}_{4}{ }^{+}(p<0.05, \mathrm{n}=48, \mathrm{r}=0.8)$. 


\section{Discussion}

Soil analyses from the study site showed differences in both physical and chemical characteristics. Percentage organic matter was higher in 2013 than 2014 (Table 3). Crop production worldwide has generally resulted in a decline in soil organic matter levels and, consequently, in a decline of soil fertility. Therefore, maintenance of soil organic matter levels and the optimization of nutrient cycling are essential to the sustained productivity of agricultural systems. The growing seasons (April-October) for 2012, 2013, and 2014 were different. During all the growing seasons, the month of July recorded the least amount of rainfall (Table 3). This resulted in inadequate soil moisture during early CC growth or late vegetative stages of sorghum growth. Overall, the amount of rainfall recorded in 2012 was less than in 2013 and 2014. Thus, the climatic conditions and soil characteristics observed during the growing season may have contributed to the variations in the results of this study.

In our study, cumulative $\mathrm{N}_{2} \mathrm{O}$ emissions were greater in fertilized cropping systems $\left(180 \mathrm{~kg} \cdot \mathrm{N} \cdot \mathrm{ha}{ }^{-1}\right.$ and $90 \mathrm{~kg} \cdot \mathrm{N} \cdot \mathrm{ha}^{-1}$ ) compared with cover crops or fallow systems without $\mathrm{N}$ fertilizer (Figure 3 ). Nitrogen fertilizer is a major contributor to $\mathrm{N}_{2} \mathrm{O}$ emissions from cultivated soils [26]. Emissions of $\mathrm{N}_{2} \mathrm{O}$ have been found to increase with $\mathrm{N}$ fertilizer rate [27], but some studies have not found consistent increases in $\mathrm{N}_{2} \mathrm{O}$ emissions with increasing $\mathrm{N}$ fertilizer rate $[28,29]$.

The use of cover crops can decrease $\mathrm{N}_{2} \mathrm{O}$ emissions from cropping systems because of their ability to decrease mineral $\mathrm{N}$ availability for $\mathrm{N}_{2} \mathrm{O}-\mathrm{N}$ producing processes [30]. Our research showed that pigeon pea and sunn hemp had significantly smaller $\mathrm{N}_{2} \mathrm{O}$ emissions than cowpea (Figure 3). The smaller emissions from pigeon pea and sunn hemp treatments in both years could be due to less water-soluble $C$, greater accumulation of $C$ and $N$, or readily decomposable organic $C$ in these plant tissues. The growth, biomass accumulation, and $\mathrm{N}$ uptake by cover crops can vary based on adaptability to specific soil and climatic conditions. Among the CC, PG had the greatest C accumulation and aboveground biomass in the relatively drier year of 2012 (338 mm rainfall during CC season), but sunn hemp performed better in the wetter year of 2013 (550 mm rainfall). Overall, performance of all CC was better in 2012 than in 2013 because rainfall was better distributed throughout the cropping season in 2012. These differences in rainfall events explain the difference in total aboveground biomass that eventually influenced $\mathrm{N}$ uptake and C accumulation of the various cover crops in 2012 and 2013. Development of crop, soil, and nutrient management practices that decrease $\mathrm{N}_{2} \mathrm{O}$ emissions would have a significant impact on atmospheric GHG levels and their subsequent effects on climate change [31].

The performance of the grain sorghum crop that followed various cropping systems was significantly influenced by $\mathrm{N}$ application and cover crops. Sorghum grain yield was significantly greater with $90 \mathrm{~N}$ and $180 \mathrm{~N}$ than in cropping systems with no fertilizer applied; however, sorghum grain yield following the three legume CC: CP, PG, and SU, with $0 \mathrm{~kg} \cdot \mathrm{N} \cdot \mathrm{ha}^{-1}$ was $42 \%, 37 \%$, and $14 \%$ greater than $0 \mathrm{~N}$, respectively, in 2013\% and 47\%, 49\%, and 44\%, respectively, in 2014 (Tables 6 and 7 ). This result suggests the contribution of $\mathrm{N}$ and $\mathrm{C}$ from the $\mathrm{CC}$ was beneficial to the following cereal grain crop [32]. It also showed that incorporation of the leguminous CC in a cereal production system can help improve $\mathrm{N}$ availability, resulting in improved biomass accumulation and grain yield of maize. Leguminous cover crop biomass is a source of organic matter that stimulates soil biologic activity and results in better nutrient and moisture management.

Previous researchers [33] have suggested that it was better to assess $\mathrm{N}_{2} \mathrm{O}$ emissions as a function of crop yield. In our study, the ratios of $\mathrm{N}_{2} \mathrm{O}$ cumulative fluxes to grain yields of sorghum in 2013 and 2014 ranged from 178 to 598 and 105 to $571 \mathrm{~g} \mathrm{~N}_{2} \mathrm{O}-\mathrm{N} \cdot \mathrm{Mg} \cdot y$ ield ${ }^{-1}$, respectively (Tables 5 and 6). Overall, in both years, $\mathrm{N}_{2} \mathrm{O}$ emissions per unit of grain yield, per unit grain $\mathrm{N}$ uptake, or per unit total $\mathrm{N}$ uptake was greatest when fertilizer $\mathrm{N}$ was added: $180 \mathrm{~N}$ followed by $90 \mathrm{~N}$ (Tables 4 and 5). This result also was reflected in emission factors, which provided the quantity of a pollutant released to the atmosphere with an activity associated with the release of that pollutant. The emission factors in both years was greater in the 180N than in 90N (Tables 6 and 7), which shows that higher emission factors are usually associated with higher $\mathrm{N}$ rates. In both years, sorghum grown after cover crops had 
greater grain yield, but $\mathrm{N}$ emissions per unit grain yield similar to that for the fallow system without $\mathrm{N}$ fertilizer. This suggests that legume cover crops supply $\mathrm{N}$ to a subsequent sorghum crop in a way that minimizes risk of $\mathrm{N}_{2} \mathrm{O}$ emissions.

The interrelationships among fertilizer $\mathrm{N}$ application, soil water content, crop growth, soil $\mathrm{N}$ dynamics, and $\mathrm{N}$ losses through $\mathrm{N}_{2} \mathrm{O}$ emissions during the season are complex. In-season $\mathrm{N}_{2} \mathrm{O}$ emissions were affected by timing of $\mathrm{N}$ fertilizer application, rainfall events, and cover crops (Figure 3 ). The first $\mathrm{N}_{2} \mathrm{O}$ emission was observed 11 to $15 \mathrm{~d}$ after fertilization and depended on the wetness of the soil during fertilizer application. In 2013, the first flux was recorded $15 \mathrm{~d}$ after urea application, which was $29.3 \%$ of the season emissions, and in 2014 it was $11 \mathrm{~d}$ after urea application, which was $33.2 \%$ of total season emissions (Figure 3). In a long-term tillage and crop rotation study on silty loam soil in Indiana, [34] researchers found that $50 \%$ of the $\mathrm{N}_{2} \mathrm{O}$ emissions occurred shortly after $\mathrm{N}$ fertilizer was applied. Nitrous oxide emissions in the fertilized plots peaked under wet conditions (WFPS $>60 \%$ ) favorable to denitrification [35]. The $114 \mathrm{~mm}$ of precipitation in June through July 2013 was significantly less than the average rainfall $(241 \mathrm{~mm})$, but contributed to the wet soil conditions, which favored high $\mathrm{N}_{2} \mathrm{O}$ losses during the latter part of the growing season. Denitrification and $\mathrm{N}_{2} \mathrm{O}$ emissions increase with higher WFPS, reaching maximum $\mathrm{N}_{2} \mathrm{O}$ emission at WFPS values from $60 \%$ to $75 \%$ and with maximum denitrification occurring at saturation [36].

Nitrous oxide emissions were greater in 2013, with losses from 1.1 to $4.5 \mathrm{~kg} \cdot \mathrm{N} \cdot \mathrm{ha}^{-1} \cdot \mathrm{year}^{-1}$ compared with 2014 losses of 0.46 to $4.4 \mathrm{~kg} \cdot \mathrm{N} \cdot \mathrm{ha}^{-1} \cdot \mathrm{year}^{-1}$. In addition to the influence of fertilizer application and rainfall events, the pool of $\mathrm{NO}^{-}-\mathrm{N}$ and $\mathrm{NH}^{+}{ }^{+} \mathrm{N}$ also can influence timing of $\mathrm{N}_{2} \mathrm{O}$ emissions [37]. The soil was low in mineral $\mathrm{N}$ content $\left(2-5 \mu \mathrm{g} \cdot \mathrm{N} \cdot \mathrm{g}^{-1}\right)$ at the beginning of emission measurements in each growing season when $\mathrm{N}$ fertilizers were not applied. Soil mineral $\mathrm{N}$ concentrations always increased after $\mathrm{N}$-fertilizer application to 15 to $100 \mu \mathrm{g} \cdot \mathrm{N} \cdot \mathrm{g}^{-1}$ soil but were never high for longer than three weeks and were always back to less than $10 \mu \mathrm{g} \cdot \mathrm{N} \cdot \mathrm{g}^{-1}$ soil at the end of the growing season. The high $\mathrm{N}_{2} \mathrm{O}$ emissions measured from mid-June through early July 2013 also corresponded to large decreases in soil inorganic $\mathrm{N}$ at both the 0 to $5-\mathrm{cm}$ and 5 to $15-\mathrm{cm}$ depths. Hence, the variability in precipitation following $\mathrm{N}$ application in both years contributed to elevated $\mathrm{N}_{2} \mathrm{O}$ emissions, especially in $90 \mathrm{~N}$ and $180 \mathrm{~N}$. Correlation between WFPS and emissions from fertilized plots was fairly strong in $2013(\mathrm{r}=0.58)$, but strong in $2014(\mathrm{r}=0.70)$, illustrating the complexity of interactions between soil water and available pools of soil $\mathrm{N}$ and their effect on $\mathrm{N}_{2} \mathrm{O}$ emissions. The positive correlation of $\mathrm{N}_{2} \mathrm{O}$ fluxes and soil $\mathrm{NO}_{3}{ }^{-}-\mathrm{N}$ content and WFPS during the entire duration of the study supports the importance of denitrification process for explaining $\mathrm{N}_{2} \mathrm{O}$ losses in this study site [38,39]. On the other hand, the strong positive correlation of $\mathrm{N}_{2} \mathrm{O}$ with $\mathrm{NH}_{4}{ }^{+}-\mathrm{N}$ indicated that nitrification was also a major process leading to $\mathrm{N}_{2} \mathrm{O}$ fluxes and showed that the continuous drying-wetting periods during summer sorghum crop in a semiarid region can lead to favorable WFPS conditions for both nitrification and denitrification processes (Figure 3). Overall, soil inorganic N in 2014 was greater than in 2013 after $\mathrm{N}$ application, which could help explain the contrasting results regarding $\mathrm{N}_{2} \mathrm{O}$ emissions.

\section{Conclusions}

Cropping systems significantly influenced $\mathrm{N}_{2} \mathrm{O}$ emissions, plant $\mathrm{N}$ uptake, C accumulation by cover crops, and grain yields of sorghum that followed various systems. Fallow systems with 180 and $90 \mathrm{~kg} \cdot \mathrm{N} \cdot \mathrm{ha}^{-1}$ produced significantly greater $\mathrm{N}_{2} \mathrm{O}$ emissions than all other cropping systems. Emissions of $\mathrm{N}_{2} \mathrm{O}$ were similar for various $\mathrm{CC}$ or $0 \mathrm{~N}$. Among various cropping systems with cover crops, pigeon pea and cowpea had greater $\mathrm{C}$ accumulation and $\mathrm{N}$ uptake than sunn hemp. Grain yield of sorghum following different cover crops was similar and usually significantly greater than $0 \mathrm{~N}$. Although the fallow systems with $90 \mathrm{~N}$ and $180 \mathrm{~N}$ produced maximum grain yields of sorghum, these yields were associated with the greatest $\mathrm{N}_{2} \mathrm{O}$ emissions per unit grain yield. The $\mathrm{N}_{2} \mathrm{O}$ emissions per unit of grain yield decreased as the amount of $\mathrm{N}$ fertilizer was reduced. We conclude that including leguminous cover crops can reduce $\mathrm{N}$ fertilizer requirements for a subsequent sorghum crop, potentially 
reducing $\mathrm{N}_{2} \mathrm{O}$ emissions per unit grain yield and providing options for adaptation and mitigation to climate change.

Author Contributions: P.V.V.P. and K.L.R. conceived and designed experiments and guided data collection and analyses. G.Y.M. carried out the experiments, collected and analyzed the data and drafted the manuscript. C.W.R. and J.B.N. guided data collection, laboratory analyses, statistical analysis, data interpretation and edited the manuscript. All authors have read and agreed to publish the final version of the manuscript.

Funding: This research was funded by the United States Agency for International Development (USAID) through the Sustainable Agricultural and Natural Resource Management-Collaborative Research Support Program (SANREM-CRSP); and Center for Sorghum Improvement at Kansas State University. Publication was supported by Feed the Future Innovation Lab for Collaborative Research on Sustainable Intensification (Grant no. AID-OAA-L-14-00006 from USAID). The contents are the sole responsibility of authors and do not reflect the views of funding agencies and organizations. Contribution number 15-343-J from the Kansas Agricultural Experiment Station.

Acknowledgments: The authors thank Peter Tomlinson, Leonardo Bastos, Andrew McGowan and Alix Carole Onmalela Bilip for assistance in measuring nitrous oxide emissions.

Conflicts of Interest: The authors declare no conflict of interest.

\section{References}

1. Robertson, G.P.; Vitousek, P.M. Nitrogen in agriculture: Balancing the cost of an essential resource. Annu. Rev. Environ. Res. 2009, 34, 97-125. [CrossRef]

2. Isermann, K. Agricultures share in the emission of trace gases affecting them climate and some cause-oriented proposals for sufficiently reducing this share. Environ. Pollut. 1994, 83, 95-111. [CrossRef]

3. Myhre, G.; Shindell, D.; Breon, R.; Collins, W.; Fuglestvedt, J.; Huang, J.; Koch, D.; Lamarque, J.; Lee, D.; Mendoza, B.; et al. Anthropogenic and natural radiative forcing. In The Physical Science Basis; Stocker, T.F., Qin, D., Plattner, G., Tignor, M., Allen, S.K., Boschung, J., Nauels, A., Xia, Y., Bex, V., Midgley, P.M., Eds.; Contribution of Working Group I to the Fifth Assessment Report of the Intergovernmental Panel on Climate Change; Cambridge University: Cambridge, UK, 2013; p. 659.

4. Portmann, R.W.; Daniel, J.S.; Ravishankara, A.R. Stratospheric ozone depletion due to nitrous oxide: Influences of other gases. Philos. Trans. R. Soc. B 2012, 367, 1256-1264. [CrossRef]

5. Reay, D.S.; Davidson, E.A.; Smith, K.E.; Smith, P.; Melillo, J.M.; Dentener, R.; Crutzen, P.J. Global agriculture and nitrous oxide emissions. Nat. Clim. Chang. 2012, 2, 410-416. [CrossRef]

6. Drury, C.F.; Reynolds, W.D.; Tan, C.S.; McLaughlin, N.B.; Yang, X.M.; Calder, W.; Oloya, T.O.; Yang, J.Y. Impacts of 49-51 years of fertilization and crop rotation on growing season nitrous oxide emissions, nitrogen uptake and corn yields. Can. J. Soil Sci. 2014, 94, 421-433. [CrossRef]

7. Fageria, N.K.; Baligar, V.C.; Bailey, B.A. Role of cover crops in improving soil and row crop productivity. Commun. Soil Sci. Plant Anal. 2005, 36, 2733-2757. [CrossRef]

8. Jensen, E.S.; Hauggaard-Nielsen, H. How can increased use of biological $\mathrm{N}_{2}$ fixation in agriculture benefit the environment? Plant Soil 2003, 252, 177-186. [CrossRef]

9. Cavigelli, M.A.; Del Grosso, S.J.; Liebig, M.A.; Snyder, C.S.; Fixen, P.E.; Venterea, R. US agricultural nitrous oxide emissions: Context, status, and trends. Front. Ecol. Environ. 2012, 10, 537-546. [CrossRef]

10. Teasdale, J.R. Interaction of light, soil moisture, and temperature with weed suppression by hairy vetch residue. Weed Sci. 1993, 41, 46-51. [CrossRef]

11. Kuo, S.; Sainju, U.M.; Jellum, E.J. Winter cover crop effects on soil organic carbon and carbohydrate in soil. Soil Sci. Soc. Am. J. 1997, 61, 145-152. [CrossRef]

12. Millar, N.; Baggs, E.M. Chemical composition, or quality, of agroforestry residues influences $\mathrm{N}_{2} \mathrm{O}$ emissions after their addition to soil. Soil Biol. Biochem. 2004, 36, 935-943. [CrossRef]

13. Garcia-Ruiz, R.; Baggs, E.M. Nitrous oxide emissions from soil following combined application of fertiliser-N and ground weed residues. Plant Soil. 2007, 299, 263-274. [CrossRef]

14. Rochette, P.; Angers, D.A.; Belanger, G.; Chantigny, M.H.; Prevost, D.; Levesque, G. Emissions of $\mathrm{N}_{2} \mathrm{O}$ from alfalfa and soybean crops in eastern Canada. Soil Sci. Soc. Am. J. 2004, 68, 93-506. [CrossRef] 
15. CTIC. Report of the 2016-2017 National Cover Crop Survey; Joint Publication of the Conservation Technology Information Center, the North Central Region Sustainable Agriculture Research and Education Program, and the American Seed Trade Association: West Lafayette, IN, USA, 2017.

16. Baranski, M.; Caswell, H.; Claassen, R.; Cherry, C.; Jaglo, K.; Lataille, A. Agricultural Conservation on Working Lands: Trends from 2004 to Present; Technical Bulletin Number 1950; Office of the Chief Economist, United States Department of Agriculture: Washington, DC, USA, 2018.

17. Hamilton, A.V.; Mortensen, D.A.; Allen, M.K. The state of the cover crop nation and how to set realistic future goals for the popular conservation practice. J. Soil Water Conserv. 2017, 72, 111A-115A. [CrossRef]

18. Eagle, A.J.; Olander, L.P. Greenhouse gas mitigation with agricultural land management activities in the United States: A side-by-side comparison of biophysical potential. Adv. Agron. 2012, 115, 79-179.

19. Mahama, G.Y.; Prasad, P.V.V.; Roozeboom, K.L.; Nippert, J.B.; Rice, C.W. Cover crops, fertilizer nitrogen rates, and economic return of grain sorghum. Agron. J. 2016, 108, 1-16. [CrossRef]

20. Parkin, T.B.; Venterea, R.T. Chamber-Based Trace Gas Flux Measurements. In Sampling Protocols; Follett, R.F., Ed.; United States Department of Agriculture: Washington DC, USA, 2010; pp. 3-39.

21. Jantalia, C.P.; Santos, H.P.; Urquiaga, S.; Boddey, R.M.; Alves, B.J.R. Fluxes of nitrous oxide from soil under different crop rotations and tillage systems in the South of Brazil. Nutr. Cycl. Agroecosyst. 2008, 82, 161-173. [CrossRef]

22. Hanlon, E.A.; Johnson, G.V. Mehlich 3 soil test extractant: A modification of Mehlich 2 extractant. Commun. Soil Sci. Plant Anal. 1984, 15, 277-294. [CrossRef]

23. Bouyoucos, G.J. Hydrometer method improved for making particle size analysis of soils. Agron. J. 1962, 54, 464-465. [CrossRef]

24. Combs, S.M.; Nathan, M.V. Soil organic matter. In Recommended Chemical Soil Test Procedure for the North Central Region, N0. 221 ed.; Brown, J.R., Ed.; NCR Publ.: Columbia, MO, USA, 1998; pp. 57-58.

25. Gelderman, R.H.; Denning, J.L.; Goos, R.J. Chlorides. In Recommended Chemical Soil Test Procedures for the North Central Region, N0. 221 ed.; Brown, J.R., Ed.; NCR Publ.: Columbia, MO, USA, 1998; pp. 53-56.

26. Stehfest, E.; Bouwman, L. Nitrous oxide and NO emission from agricultural fields and soils under natural vegetation: Summarizing available measurement data and modeling of global annual emissions. Nutr. Cycl. Agroecosyst. 2006, 74, 207-228. [CrossRef]

27. Kim, D.G.; Hernandez-Ramirez, G.; Giltrap, G. Linear and nonlinear dependency of direct nitrous oxide emissions on fertilizer nitrogen input: A meta-analysis. Agric. Ecosyst. Environ. 2012, 168, 53-65. [CrossRef]

28. Van Groenigen, J.W.; Kasper, G.J.; Veltho, G.L.; van den Pol-van Dasselaar, A.; Kuikman, P.J. Nitrous oxide emissions from silage maize fields under different mineral nitrogen fertilizer and slurry applications. Plant Soil. 2004, 263, 101-111. [CrossRef]

29. Adviento-Borbe, M.A.A.; Haddix, M.L.; Binder, D.L.; Walters, D.T.; Dobermann, A. Soil greenhouse gas fluxes and global warming potential in four high yielding maize systems. Glob. Chang. Biol. 2007, 13, 1972-1988. [CrossRef]

30. McSwiney, C.P.; Snapp, S.S.; Gentry, L.E. Use of N immobilization to tighten the N cycle in conventional agro ecosystems. Ecol. Appl. 2010, 20, 648-662. [CrossRef] [PubMed]

31. Calderia, K.; Morgan, M.G.; Baldocchi, D.; Brewer, P.G.; Chen, C.T.A.; Nabuurs, G.T.; Nakicenovic, N.; Robertson, G.P. A portfolio of carbon management options. In The Global Carbon Cycle; Field, B., Raupach, M.R., Eds.; Island Press: Washington, DC, USA, 2004; pp. 103-130.

32. Cheruiyot, E.K.; Mumera, L.M.; Nakhone, L.N.; Mwonga, S.M. Rotational effects of legumes on maize performance in the rift valley highlands of Kenya. J. Afr. Crop. Sci. 2001, 9, 667-676. [CrossRef]

33. Van Groenigen, J.W.; Velthof, G.L.; Oenema, O.; van Groenigen, K.J.; van Kessel, C. Towards an agronomic assessment of $\mathrm{N} 2 \mathrm{O}$ emissions: A case study for arable crops. Eur. J. Soil Sci. 2010, 61, 903-913. [CrossRef]

34. Omonode, R.A.; Smith, D.R.; Gál, A.; Vyn, T.J. Soil nitrous oxide emissions in corn following three decades of tillage and rotation treatments. Soil Sci. Soc. Am. J. 2010, 75, 152-163. [CrossRef]

35. Mosier, A.R.; Doran, J.W.; Freney, J.R. managing soil denitrification. J. Soil Water Conserv. 2002, 57, 505-512.

36. Almaraz, J.J.; Mabood, F.; Zhou, X.M.; Madramootoo, C.; Rochette, P.; Ma, B.L.; Smith, B.L. Carbon dioxide and nitrous oxide fluxes in corn grown under two tillage systems in southwestern Quebec. Soil Sci. Soc. Am. J. 2009, 73, 113-119. [CrossRef] 
37. Hellebrand, H.J.; Scholz, V.; Kern, J. Fertilizer induced nitrous oxide emissions during energy crop cultivation on loamy sand soils. Atmos. Environ. 2008, 42, 8403-8411. [CrossRef]

38. Davidson, E.A. Fluxes of nitrous oxide and nitric acid from terrestrial ecosystem. In Microbial Production and Consumption of Greenhouse Gases: Methane, Nitrous Oxide and Halomethane; Rogers, J.E., Whitman, W.B., Eds.; American Society of Microbiology: Washington, DC, USA, 1991; pp. 219-236.

39. García-Marco, S.; Ravella, S.R.; Chadwick, D.; Vallejo, A.; Gregory, A.S.; Cárdenas, L.M. Ranking factors affecting emissions of GHG from incubated agricultural soils. Eur. J. Soil Sci. 2014, 65, 573-583.

(C) 2020 by the authors. Licensee MDPI, Basel, Switzerland. This article is an open access article distributed under the terms and conditions of the Creative Commons Attribution (CC BY) license (http://creativecommons.org/licenses/by/4.0/). 